\title{
The concept of value in modern youth subcultures of K-pop and Brony in the period of globalization
}

\author{
Evgeny Nesmeyanov ${ }^{1,}$, Yulia Petrova $^{2}$, Rupia Bachieva ${ }^{3}$, and Olga Vasichkina ${ }^{4}$ \\ ${ }^{1}$ Don State Technical University, 344022, Rostov-on-Don, Russia \\ ${ }^{2}$ Rostov State University of Economics (RSEU), 344002, Rostov-on-Don, Russia
}

\begin{abstract}
The relevance of the research topic is that global youth culture is an interdisciplinary category, with the help of which analysts try to understand the emergence of complex forms of cultural identity and hybridity, which can be found more often among young people around the world and that is directly related to the media (cinema, television, popular music, Internet). To use the analogy with K-pop and Brony youth subcultures, the authors show the similarities between two subcultures on specified grounds, where values define manners and norms of behavior, which are valuable in youth subcultures, gained its worldwide popularity through like-minded friends in online communities where fans are an integral part. The inductive method encourages philosophize about the general picture of two modern youth subcultures to particular moments, i.e. dominant social values in their public actions in both subcultures. Using the method of generalization, the authors consider the value concept of "loyalty" for young people in the context of the phenomenon of fans using the example of K-Pop and Brony subcultures. The most important characteristic of group life is that it has a set of values that govern the behavior of members of the entire group.
\end{abstract}

\section{Introduction}

The values of K-pop and Brony subcultures are an important component in the construction of identity, and the peculiarities of the positive characters are that its representatives do not highlight drugs and violence to the forefront. The characteristics of youth subcultures are their attempt to show the world in bright colors with a degree of naivety, without touching upon serious problems so that the younger generation does not feel lonely and unnecessary. After all, who can better understand youth, if not youth by itself, which is precisely the driving force of any youth subculture?

An important characteristic of group life is that it has a set of values that govern the behavior of group members. A subculture does not appear out of nowhere with stable relationships between members; it represents the result of activities and / or interactions between young people.

\footnotetext{
${ }^{*}$ Corresponding author: nesmeyanoff.e@yandex.ru
} 


\section{Theoretical and methodological principles of the study of values as a way of behavior}

According to the research of M. Rokich [12, p. 124, 160], values are global. Beliefs that "transcendently direct actions and judgments on specific objects and situations." B. Pozner and W. Schmidt describe values as "underlying at the basis of human being, that influence the choices made by people ... and how people and organizations invest their energy equally" [25, p. 277], R. Fazio, I. Ajzen, \& M. Fishbein consider the manifestation of fundamental values - behavior [7], [16].

Many modern researchers argue that values are predictors or, at least, precursors to actual behavior [5, p. 67-73], [15, p. 638-646], [19, p. 37-54]. A variety of concepts produce ambiguous concepts of value ... "... as goals, interests, needs, personality types, motivation, relationships, etc." [2, p. 351-389]. This lack of agreement has created problems in interpreting the results of various studies [3, p. 388-433], [17, p. 16]. Nevertheless, it seems that among the researchers we see significant agreement on the importance of values that influence on behavior. It is believed that values have a significant impact on the emotional and behavioral reactions of people [4, p. 1297-1349], [13] and "directly influence on behavior" in the sense that they encourage people to act in accordance with their values [6], [17 c. 16]. The norm of behavior, as a convention, is a representative or typical model and rules of behavior in a group of people [23, p. 116]. In our consideration of youth subcultures, the use of the norm is standard behavior, "typical" for groups. Whether norms are the average behavior of individuals in groups remains an open question and depends on the level of compliance. Compliance and non-compliance with these norms are characteristics of individuals, and, of course, heterogeneity in these symbols, all these are important for the development of norms. Thus, it is the values that determine the behavior which is socially desirable in a particular youth subculture, which encourages young people to comply with the dominant social values in their public actions in a particular subculture.

\section{Trends in globalization and multiculturalism in modern subcultures of K-pop and Brony}

The scholarly papers on the topic of values are extensive, and in the methodological part of the study we consider relevant with regard to young subcultures, formed with significant support from the media and the Internet.

According to "We Are Social and Hootsuite", since January 2017, there have been 5 million more Russian Internet users - the increase amounted to 4 per cent, and 9 million more people now use social networks $(+15$ per cent from the last year's figure). 85 per cent of people in Russia are online daily. 91.4 million people are using mobile Internet in the world very actively [27].

The generation gap exists in almost all aspects of social and personal areas; it is never more obvious than in the field of technology. The Ipsos MORI Institute for Social Research cited the following data: where $77 \%$ of Millennials, also known as generation $\mathrm{Y}$ use the Internet more than 1 time per day, generation $\mathrm{X}-68 \%$, and the Baby Boomers generation (also known as boomers) $-49 \%$, i.e. only $16 \%$ of the pre-war generation are online [1], [5]. This percent shows that the intergenerational gap is connected with digital technologies and depends on the stage of continuum of the adulthood, where one is considered to be the generation digital natives and others are immigrants or even foreigners.

The parallel trends of globalization and multiculturalism make the development of subcultures increasingly important, for deeper understanding of various manifestations in 
culture. From year to year, subcultural influences change fundamentally, as cultures are no longer dependent on local resources to formulate their characteristic tastes, preferences and behavior and are increasingly interconnected through the vast geographical distances of cities, countries and continents by modern means of communication, as a result of which, subcultures of Russian society can be compared with similar processes in the whole world at the beginning of the XXI century.

"This is due to the general tendency of modern developed societies to multiculturalization, which is expressed in the disintegration of the unity of the hierarchy of dominant values and the creation of diverse, eclectic and fragmented forms of cultural identity."

Self-construction of personality with the availability of the Internet "has led to an abundance of its new forms associated with youth subcultures ... " [22] for example, the popular k-pop direction in Russia (abbreviation from the English Korean pop) [11, p. 61], which is characterized by vivid images, complex choreography and non-standard sounding - this is just a short list of what includes the popular, especially among young people, direction in music. The phenomenon of Korean culture, which in the last decade has gained strength in the East and rushed to the West, is an inexplicable fact for many people. However, the concept of "Korean wave" or, as it is also called "Hallyu" appeared in the mid-90s and signifies the spread of modern Korean culture throughout the world. In the 90s, this phenomenon was known only in Asia, the very spread of Korean culture around the world was ghostly, now the "Hallyu stars" bring huge sums of money to the budget of their state, and their popularity is growing not only among Asian youth, but also in the whole world [26, p. 92].

The "Korean wave" includes not only the popular genre of k-pop music, but also series called "dramas", as well as TV shows, which have also gained popularity among those who are fond of Asian pop culture. K-pop can be described as a kind of mix of various genres of music, in particular, such as: Western electro-pop, hip-hop, dance music and modern rhythm and blues. In order to listen to the combination of genres does not necessarily apply to all aspects of cult significance in music, a partial connection with the redefinition of symbolic meaning by symbolic associations, with many unknown passages of music due to their own cultural associations contributes to the popularity of K-pop both in the West and in the East. It should be noted that "... music is the result of a long process of cultural integration, which contributed to the cultural transfer of musical characteristics, such as emotional expression, which can be a common denominator of perception for many musical cultures" [21, p. 513-518]. Today k-pop is not just a "funny music", but a progressive genre, a large-scale musical subculture with millions of fans around the world (idols) - young people with impeccable looks, incredible dancing skills, unusual vocals and with an exceptionally good reputation. Appearance plays an important role for "idols", which indicates the "changes the value of consciousness" of youth in the last decade [20].

\section{K-pop subculture - values of the fandom}

It should be noted that, as in any pop industry, fans are an integral part, and representatives of k-pop culture are not exceptions. Each group has its own "fandom" with its own name, which is assigned by the company of "idol group". Agencies also issue special symbols related to the group, it includes: special light sticks, jewelry, clothes, posters, photographs and many other things.

Fans are happy to buy these things and even ask companies to give the name of the "fandom" and release a specialized "merch", because these are the things that distinguish idol group fans from each other, and the groups by themselves can be immediately recognized by their fans, all these make k-pop culture unique. There is a tendency that fans 
may also belong to different "fandoms", because the number of "idol groups" increases significantly every year.

Korean and other Asian fans more often belong to one or more "fandoms", that is, they still more clearly choose "their favorites" by voting for them on music shows and buying symbols of the group. But foreign fans are still less local in their choice, classify themselves as k-pop culture itself. This does not mean that foreign fans do not join the "fandom", they also follow their favorite artists and support them, but also more openly express their love for the common "idol culture" [24].

So, k-pop culture is not just a music genre, which is popular in Asia, it is a real progressive subculture with its symbols, demeanor and language. The system itself, thanks to which k-pop has become popular all over the world, is a multi-stage complex process of making young people into k-pop icons.

\section{Values of the fandom - Brony subculture}

When several people interact, a set of standards arises, which regulates the relationships and behavior inside the group, so a completely new subculture was born - "Brony" from (brother and pony) or "Pegasister" (used for community members). The history of this subculture began with the viewing of the Canadian-American TV series "My Little Pony: Friendship is Magic" - Friendship is a miracle, at the end of 2010. Most people considered them as a random hobby, a meme that would disappear faster than it appeared, but the phenomenon did not disappear - it flourished.

Fans searched for each other on the net and created places for meeting. Now they are everywhere: fan blogs, Tumblr, Ponychan, etc., meetings and conventions that attract thousands of people. The reasons why people enjoy the fandom are complex, partly because of gender assumptions surrounding the show and its audience. The values of the fandom - are care, generosity and kindness, these character traits were more common for girls, and therefore men who like "brother" are often ridiculed, which explains why it would be reasonable to admit incognito belonging to a new subculture. Identity is not an easy thing, and an adult in a t-shirt of My Little Pony can often not be understood. It is much easier to find like-minded friends on the Internet. And yet, from a small online community of fans, Brony has grown into a pop culture phenomenon. Fandom disputes the traditional concepts of masculinity, especially by adopting the pony mantra - love and tolerance. This topic improves interpersonal relationships. Brony creates a new construct of masculinity, called discordant masculinity, which avoids post-feminist attributes in other people, "hybrid" forms of masculinity. On the topic of Brony subculture, master's theses, dissertations are written (J. Mountford "Creating Masculinity Online: Brony")[8], educational programs are composed (L. Shafirova, D. Cassani, the University of Pompeu Fabra (UPF)) [10], the interest is also shown in scientific research - the Center for Youth Studies (CYS) of Russia, founded in 2009 as a partnership project between the Scientific Research University (SRU) St. Petersburg and the Research Center "Region" of the Ulyanovsk State University, they publish on its website the following materials: "On the Russian Brony-scene" there are such conventions as RuBronyCon (Moscow), Ponyrebrik (St. Petersburg), joint Brony festivals are held in Moscow and St. Petersburg, Brony community is 118 thousand people in Russian social link VK etc.

\section{Conclusion}

Thus, in the subcultures of the XXI century, there are two main forms of interaction between members of the fan club: virtual communication and personal contact. Some 
representatives of this subculture take part in the exchange of ideas between participants through web chats or web forums; others are involved in events organized by the fan club, such as K-pop and Brony. It was also established that fans, despite the language barrier and the values of dominant cultures, experience not a negative, but a positive impact in the process of interacting with other members of their fan clubs.

This is determined by comparing fans of his / her real rewards with the costs of fan clubs. In other words, the components of fan clubs consist of three positions: involvement, satisfaction and belonging. Fan researchers try to distinguish fans from followers [9] or from consumers [18, p. 67-88]. So the critical characteristics of "fans" are that they are not just "passive recipients of a media product", but also active participants in the fandom as a social, cultural and interpretative institution [6, p. 1-39], [18, p. 67-88].

Researchers also identify a number of motives for becoming a fan: attraction, identification with the heroes of the children's animated series or pop stars, etc., which may be the subject of further research.

The values by studied the subcultures do not stand in opposition to the dominant cultural norms and values of the society. K-pop and Brony subcultures focus on specific styles, values, or practices which distinguish them from broader parent cultures and their styles, values, or practices. The fact that the members of the subculture and their fans act, dress or think differently from the parent cultures does not mean that they rebel or oppose the parent culture; in our opinion, they simply strive to be different and honestly express themselves. Therefore, for us, modern subcultures are "an imaginary or socially built community that has a fairly distinctive form or structure, which makes them not like the parent culture".

Although they should focus on certain activities, values or ideologies that significantly distinguish them from a wider culture, there should also be hidden aspects of their activities, values that connect them with other members within the group. Fans of K-Pop and Brony have the opportunity to identify symbolic double meanings in seemingly ordinary objects that are known to every member of the subculture. There is no official registration or application for membership to participate in the subculture; for this, it is enough to be fans and simply externally demonstrate specific values, style or practices that are central to the internal discourse of the subculture. The values of freedom, individualism, authenticity and inconsistency form the basis of the style and practice of members of the subculture and are the only requirement for membership and "joining" the ranks of "their own".

\section{References}

1. A. Tank, Why More Knowledge Won't Make You More Successful, information on: https://www.entrepreneur.com/article

2. B. M. Maglino, E. C. Ravlin, Individual values in organizations: Concepts, controversies, and research, MJ, 24 (3), 351-389 (1998)

3. C. Kluckhohn, Values and Value-Orientations in the Theory of Action: An Exploration in Definition and Classification, 388-433, (1951)

4. E. A. Locke, The Nature and Causes of Job Satisfaction, in M. D. Dunnette (ed.), Handbook of Industrial and Organizational Psychology, 1297-1349 (1976)

5. G. M. Malik, R. Akhter, Existentialism and Classroom Practice, IOSR-JHSS, 8(7), 87-71 (2013)

6. G. S. Stever, Parasocial and social interaction with celebrities: Classification of media fans, MP, 14(3), 1-39 (2009) 
7. I. Ajzen, M. Fishbein, Understanding Attitudes and Predicting Social Behavior, information on: http://www.sciepub.com/reference/105149

8. J. B Mountford, Creating Masculinities Online: Bronies and The Red Pill, Dissertation (2014-2015).

9. J. Tulloch, H. Jenkins, Science fiction audiences: Watching doctor who and star trek (1995)

10. L. Shafirova, D. Cassany, Bronies learning English in the digital wild, LLT, 23(1), 127-144 (2019)

11. M. Fuhr, Globalization and Popular Music in South Korea: Sounding Out K-Pop, 61, (2016)

12. M. Rokeach, Beliefs, Attitudes, and Values, 124, 160, (1968)

13. M. Rokeach, The Nature of Human Values (1973)

14. P. E. Connor, B.W. Becker, Personal Values and Management: What do we Know and why don't we Know More?', MI, 3(1), 67-73 (1994)

15. P. M. Homer, L. R. Kahle, A Structural Equation Test of the Value-Attitude-Behavior Hierarchy, PSP, 54, 638-646 (1988)

16. R. H. Fazio, How do Attitudes Guide Behavior? (1986)

17. R. M. Williams, Change and Stability in Values and Value Systems: A Sociological Perspective, 16 (1979)

18. R. V. Kozinets, Utopian enterprise: Articulating the meanings of Star Trek's culture of consumption, CR, 28(1), 67-88 (2001)

19. R. W. Stackman, C. C. Pinder, P. E. Connor, Values Lost: Redirecting Research on Values in the Workplace, 37-54 (2000)

20. S. Burilkina, The study of values and value-based guidelines of students in the transforming society, HSE \& SS (2016)

21. T. H. Fritz, The Dock-in model of music culture and cross-cultural perception, MP, 30, 513-518 (2013)

22. T. V. Gavrilyuk, V. A. Garabazhiy, L. M. Gaysina, L. Gabdrakhmanova, I. V. Burenina, Dynamics of global youth subcultures and movements: Russian context, GMJ, 2:10 (2016)

23. W. G. Sumner, Folkways: A study of the social importance of usages, manners, customs, mores, and morals, 116, (1911)

24. Yu. Samartseva, What is k-pop and why is it being listened to? (2018), information on: https://www.parafraz.org/single-post/что-такое-k-pop

25. Z. B. Posner, W. H. Schmid, The Values of Business and Federal Government Executives: More Different Than Alike, PPM, 25(3), 277-290 (1996)

26. Korean Culture and Information Service South Korea, K-POP: A New Force in Pop Music, $92 \quad$ (2011), information on: https://issuu.com/kocis9/docs/the_korean_wave_2011.

27. Information on: https://www.web-canape.ru/business/internet-2017-2018-v-mire-i-vrossii-statistika-i-trendy/, Internet 2017-2018 in the world and in Russia: statistics and trends. 